\title{
Digital Media and Young Children's Learning: A Case Study of Using iPads in American Preschools
}

\author{
Lena Lee
}

\begin{abstract}
This paper explores a project with young children from low-income preschools by emphasizing young children's learning with digital media. It focuses on a case study with young children (age 3-5) and their uses of iPads in Head Start and public school preschool programs in a Midwest area of the United States. It discusses how young children's learning can be supported by digital media use with specific examples.
\end{abstract}

Index Terms-Digital media, young children, iPad as a learning tool.

\section{INTRODUCTION}

In the contemporary experience of childhood, children use not only traditional, typical toys and materials such as blocks, dolls, balls, puzzles, sand, but also, they interact on a daily basis with technology like digital media. Given the different aspects of children's lives and childhood, it is necessary to reconceptualize young children's play in current society. Young children frequently use digital interactive technologies as one of the dominant activities in their play experiences: these technologies can include objects such as mp3 players, iPods, iPads, game apps, and televisionso-called, "digital media" [1]-[3]. Ref. [2], [3] these young children live in the technology era, and their exposure to and uses of digital media has changed the modality of their current family lives, their ways of communicating, and their methods of learning [4].

As a result, it is critical to reflect how differently young children play, learn and communicate, and what we can do to help them learn best with digital media. A significant body of research compiled over the past couple of decades has found that a well-designed digital media curriculum is effective in enhancing young children's learning (e.g., [5]-[11]). Some research studies [12], [13] have indicated that digital media use supported the development of young children's mathematical and cognitive skills. Moreover, this kind of use of digital media can support enhancements to their attention and concentration levels, consistency, and knowledge expansion and applications [14].

Therefore, this paper explores how early childhood classrooms can use digital media for young children's learning more effectively, as a way of providing information to early childhood professionals and educators who are interested in using digital media for young children's

Manuscript received May 10, 2014; revised August 12, 2014. This research project was supported by the PNC foundation.

Lena Lee is with Miami University, Oxford, Ohio, USA (e-mail: leel@miamioh.edu). learning. It particularly looks closely at the inclusion of iPads in early childhood curriculums of low income preschools, and it examines how iPad usage can be helpful for young children's learning in terms of developing their social skills and motivation.

\section{Methodology}

\section{A. IPad App Selection and Implementation}

The iPad apps used in the preschool classrooms were selected to help meet the teachers' learning goals for development and learning. They were evaluated and selected, based on an adoption of the major criteria suggested by Hillman and Marshall (2010) (see the Table I) [15]. One of the apps focused on enhancing the students' understanding of math number line concepts, whereas another focused on science concepts of weather and animals, and yet another one concentrated on cultivating understanding of social studies concepts of rules/responsibilities and emotions. The apps were selected for their high level of interactivity. I did not choose any literacy related apps because this project was particularly geared towards developing the children's math/science learning, as well as their social knowledge and skills. This paper focuses on young children's learning process by exploring how these children worked with the iPad to make their learning meaningful with teacher figures such as my students and me. It is important to note that this paper discussion is a part of a larger research study.

The first week of the project was for pre-assessing the children's learning ability and introducing the iPad to the children. During this time, the children had time to explore and experiment with the iPad and the apps with my students and me. For two to three weeks after the initial introductory week, the children used an iPad in a learning center with an app geared towards math, social studies, and science. They used the iPad for 45 minutes, twice per week, for one semester. Finally, at the end of the semester, the children were administered a post assessment.

\section{B. Schools}

Two low-income preschools in a Midwestern area of the United States participated in this study. At both schools, the children's learning levels were very low. One was a Headstart program and the other was a public preschool. The Headstart school had $100 \%$ of students who were eligible for free or discounted lunches. It had two main teachers and two assistant teachers with four classes, all of which were half-day. Each class had 14-17 children aged 2.5- to 5- years of age. Several of children (approximately 25 to $35 \%$ of the children) had mild to severe behavioral problems and there 
were 2 to 3 children per class who were ELL (English Language Learners).

TABLE I: Five DOMAINS FoR SELECTING IPAD APPS FOR YOUNG CHILDREN

\begin{tabular}{|c|c|c|}
\hline Domain & Central question & Criteria questions \\
\hline Interactivity & $\begin{array}{l}\text { Is the role of the child integral } \\
\text { to the activity? }\end{array}$ & $\begin{array}{l}\text { - Does it allow the child to actively participate? } \\
\text { - Does it promote critical and creative thinking? } \\
\text { - Does it model decision making and positive problem solving? }\end{array}$ \\
\hline Digital literacy & $\begin{array}{l}\text { Does it increase the child's } \\
\text { familiarity and ability with } \\
\text { technology? }\end{array}$ & $\begin{array}{l}\text { - Does it help the child make sense of the world? } \\
\text { - Does it teach the child to explore safely? }\end{array}$ \\
\hline Appropriateness & $\begin{array}{l}\text { Is it targeted to young } \\
\text { children? }\end{array}$ & $\begin{array}{l}\text { - Does it allow the child to experience multiple domains? } \\
\text { - Does it contain significant content and outcomes? } \\
\text { - Is the digital experience challenging but not frustrating? } \\
\text { - Does the digital world present a positive virtual universe? }\end{array}$ \\
\hline Results & $\begin{array}{l}\text { Does it provide knowledge of } \\
\text { results a child can } \\
\text { understand? }\end{array}$ & $\begin{array}{l}\text { - Is there a clear and understood connection between the child's actions and learning responses and the } \\
\text { program (app)'s results? } \\
\text { - Actions and learning responses and the program (app)'s results? } \\
\text { - Is feedback incorporated regularly to guide the child's performance rather than as a display of a } \\
\text { - Is the feedback easy to interpret? }\end{array}$ \\
\hline Participation & $\begin{array}{l}\text { Does the program promote } \\
\text { participation (collaboration) } \\
\text { among children, parents, and } \\
\text { teachers? }\end{array}$ & $\begin{array}{l}\text { - Are there program components that provide parents, caregivers, and teachers with information on the } \\
\text { program's goals, ways to participate, the child's experience, and ways to evaluate the child's } \\
\text { experience? } \\
\text { - Is the learning experience enhanced when parents, caregivers, or teachers participate with the child? }\end{array}$ \\
\hline
\end{tabular}

The other public preschool had over $86 \%$ of students who were eligible for free or discounted lunches. It had two main teachers and three assistant teachers with four classes, all of which were half-day. Each class had 16-17 children aged 3to 5- years. More than one fourth of the children had mild to severe hearing and speech impairments, and there were 1 or 2 children per class who were ELL (English Language Learners).

\section{FINDINGS}

\section{A. Social Interaction and Collaboration}

The children's use of an iPad in a learning center enhanced the children's frequent interactions with their peers and their teachers because they were not merely playing and using with an iPad alone. They consistently engaged in discussion with their peers and their teachers when they had a task on the iPad. Because a teacher was always with them in the center, the children were encouraged to learn not only how to have divergent thinking to solve a problem with an iPad, but also, how to work together to solve it by thinking, discussing, and communicating with the teacher and their peers. For instance, they talked about the possibilities of solving a problem and they tried different ways to resolve it as a group. When they tried to solve a science problem about seasons in an app, the children helped each other by providing directions, showing each other how to do the problem, and asking questions of each other with me:

Child 1: This is spring! So I am going to do...Uh-oh. This is not spring...(looking puzzled)

Child 2: Hey, why do you think it is spring?

Child 1: Cause it [the tree leaf] has a color. Pretty. See? I was born in spring, too!

Me: Well, that is a great point. But what color do usually the tree leaves have?
Child 1: Yellow... and brown.

Child 2: Yeah! (pointing out a specific part of the tree leaf on the iPad) This is really brown.

Me: Right. Then do you remember what color the tree leaves usually have in the spring?

Child 1: Green...?

Me: Yes, but you know sometimes, tree leaves are green in the spring.

Child 2: Yeah!

Me: Then, how can you figure this picture [in the iPad app] out if this is spring or fall? What are these two pictures [in the iPad app] different other than colors?

Child 1: This has.... lot of leaves and this [the other one] doesn't.

Child 2: And that one has the leaves on the ground.

Child 1: Yes, but this one doesn't have the leaves on the ground. And, and, it doesn't have many leaves on the tree sticks, here [touching the tree on the iPad].

Me: Yes! It is called "branches." So we should look for at least two things to figure out here.

What and what?

Child $1 \& 2$ : Color and leaves on the ground!

[laughing]

Me: Yes, if a lot of leaves are on the branches or on the ground. Right? Then what season can this [in the iPad app] be?

\section{Child 1 \& 2: Fall!!}

Children also presented their ideas easily to their peers and communicated with them more effectively with their pictures, drawings, and writings. As a result, in working with their peers and me, these children often checked back with each other and they had appropriate scaffolding from me.

\section{B. Ownership and Motivation of Learning}

Most children had an increasing amount of time spent being engaged with an iPad, and this experience also 
increased their interest in learning by playing iPad apps. Their motivation to learn increased because their interactions with digital media were engaging and fun. This high motivation led them very engaged in individual learning as well as for a small group activities. I observed a 3-year-old child who tried to solve a problem of counting numbers with the iPad while I was with him:

Child: Well, well, well... I thought I knew the answer. But I don't!

Me: Do you need help?

Child: (Looking at me) I don't know why my answer is wrong. See...? Here are five bananas... and here are two.

Me: You are right. But you know what? There is only one place, here, you can put the numbers of the bananas all together. Not each of those.

We call it "adding."

Child: Ahhhh...! Ok. I think I've got it now! I want to do it again. I will go back by pushing this button... and now...let me show you how I can do with it, "adding." I do know how to do this!

This child did not give up on the challenge when solving the problem. Rather, he wanted to show "how he can do with it, adding," to me. There were many children like him having high motivation and trying a problem over again until they would completely understand it. It would not be an easy task because they needed a great level of patience and self-regulation in addition to their ability to learn a content with which they were not fully familiar. However, they took ownership of their learning and continued to try. Furthermore, these children were confident and motivated to use the iPads because these tools were very easy to handle and manipulate, even by students whose fine-motor skills were not yet fully developed. Therefore, they were very excited to see my students and me because they knew they would learn.

\section{CONCLUSIONS}

In considering technology a significant part of a child's life, this paper explored how young children could use digital media more effectively for their learning by looking at a case study with the iPad being used in two preschools. The inclusion of technology tools such as the iPad allowed young children to have meaningful conversations with peers and teacher figures such as my students and me, and it enhanced their motivations and ownership of their learning.

The project of using iPads for young children's learning that this paper briefly discussed was not a simple task. It was also intertwined with how to develop an early childhood curriculum, plan lesson plans, and assess children's learning even before the project started until the end of it. From this point of view, it is necessary to ponder how early childhood teachers and professionals help young children build fundamental learning, to have more enjoyable learning experiences, and to connect their learning to their interests, needs, and culture at school.

As a result, questions related to young children's uses and favoritism of digital media is not a matter of if or not early childhood classrooms should use such technologies any more.
Instead, early childhood professionals should think of appropriate but proactive pedagogical approaches that can be developed for young children's learning and their play with digital media. In order to do so, I propose that teachers have a very important need to have support and experiences in using digital media: It is crucial to provide thoughtfully designed professional development opportunities to help early childhood education teachers develop both operational and functional competence in using classroom technologies effectively. I believe that, once they are familiar with the media and have had ample opportunity to use it in their classrooms, positive outcomes for children's learning can be expected (e.g., [16]-[18]).

\section{REFERENCES}

[1] I. R. Berson and M. J. Berson, High-Tech Tots: Childhood in a Digital World, Charlotte, NC: Information Age Publishing, 2010.

[2] National Association of the Education for Young Children. (2012). Technology and Interactive Media as Tools in Early Childhood Programs Serving Children from Birth through Age 8. [Online]. Available:

http://www.naeyc.org/files/naeyc/PS_technology_WEB.pdf

[3] V. J. Rideout, A. Lauricella, and E. Wartella. (May 29, 2013). Children, Media, and Race: Media Use among White, Black, Hispanic, and Asian American Children. Evanston, IL: Center on Media and Human Development, School of Communication, Northwestern University. [Online]. Available: http://web5.soc.northwestern.edu/cmhd/wp-ontent/uploads/2011/06/S OCconfReportSingleFinal-1.pdf

[4] V. J. Rideout and E. Hamel, The Media Family: Electronic Media in the Lives of Infants, Toddlers, Preschoolers and Their Parents, Menlo Park, CA: Kaiser Family Foundation, 2006.

[5] L. J. Couse and D. W. Chen, "A tablet computer for young children? Exploring its viability for early childhood education," Ournal of Research on Technology in Education, vol. 43, no. 1, pp. 75- 98, 2010.

[6] F. Din and J. Calao, "The effects of playing educational video games on kindergarten achievement," Child Study Journal, vol. 31, pp. 95-102, 2001.

[7] P. Greenfield, "Developmental considerations for determining ppropriate internet use guidelines for children and adolescents," Applied Developmental Psychology, vol. 25, pp. 751-762, 2004.

[8] M. T. Heft and S. Swaminathan, "The effects of computers on the social behavior of preschoolers," Journal of Research in Childhood Education, vol. 16, no. 2, pp. 162-174, 2002.

[9] H. L. Kirkorian, E. A. Wartella, and D. R. Anderson, "Media and young children's learning," The Future of Children, vol. 18, pp. 39-61, 2008.

[10] L. McGee and D. Richgels, "Can technology support emergent reading and writing? Directions for the future," in M. McKenna, L. Labbo, R Kieffer, and D. Reinking Eds., International Handbook of Literacy and Technology, vol. 2, pp. 369-377, Mahwah, NJ: Erlbaum, 2006.

[11] D. H. Clements and J. Sarama, "Lisenbee, whiteboards and websites: Digital tools for the early childhood curriculum," Young Children, vol. 64, no. 6, pp. 92-95, 2009.

[12] D. H. Clements and J. Sarama, "Young children and technology: What does the research say?" Young Children, vol. 58, no. 6, pp. 34-40, 2003.

[13] R. S. Klibanoff, S. C. Levine, J. Huttenlocher, M. Vasilyeva, and L. V. Hedges, "Preschool children's mathematical knowledge: The effect of teacher 'math talk'," Developmental Psychology, vol. 42, no. 1, pp. 59-69, 2006.

[14] L. Plowman, O. Stevenson, C. Stephen, and J. McPake, "Preschool children's learning with technology at home," Computers \& Education, vol. 59, no. 1, pp. 30-37, 2012.

[15] M. Hillman and J. Marshall, "Evaluation of digital media for emergent literacy," Computers in Schools, vol. 25, no. 4, pp. 256-270, 2010.

[16] M. E Bausch, and T. S. Hasselbring, "Assistive technology: Are the necessary skills and knowledge being developed at the preservice and inservice levels?" Teacher Education and Special Education, vol. 27, pp. 97-104, 2004

[17] C. Blum, H. P. Parette, and H. H. Watts, "Engaging young children in an emergent literacy curriculum using of Microsoft PowerPoint TM Development, considerations, and opportunities," in A. M. Vilas, A. S. 
Martin, J. M. Gonza'lez, and J. A. Gonza'lez, eds., Research, Reflections and Innovations in Integrating ICT in Education, vol. 1, pp 41-45, Badajoz, Spain: Formatex, 2009.

[18] H. P. Parette, J. B. Stoner, and E. H. Watts, "Assistive technology user group perspectives of early childhood professionals," Education and Training in Developmental Disabilities, vol. 44, pp. 257-270, 2009.

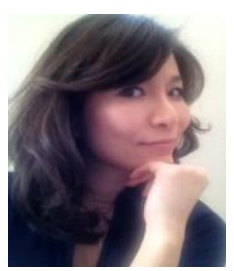

Lena Lee is an associate professor of early childhood education at Miami University of Ohio, USA. She earned the doctorate of early childhood education in Indiana University, Bloomington, USA, and the D.E.A. of comparative women's studies at Paris VIII University, France. Her research interests are focused on teaching, and professional service are on examining what social values and assumptions about learning and teaching (e.g., media, technology and diversity in early childhood classrooms), in the field of early childhood education and how differently or similarly those are implemented in various socio-cultural contexts. Her work has often speculated how to foster multicultural teacher/education in global community. She was the first awardee of Emerging Scholar Award of American Educational Research Association (AERA), Critical Perspective of Early Childhood Education SIG. Her recent project discussed in this paper was externally funded by PNC foundation of the United States. She has been elected as the Region 5 (Illinois, Indiana, Michigan, Minnesota, Ohio, \& Wisconsin) the representative at the National Association for Early Childhood Teacher Educators (NAETEC) and as the vice present of the Korean-American Early Childhood Education Researchers Association (KECERA). She also serves on several other professional organizations and research journals. 